\title{
BIOECOLOGY AND CHEMICAL DIVERSITY OF ABDOMINAL GLANDS IN THE IRANIAN SAMSUM ANT Pachycondyla sennaarensis (Formicidae: Ponerinae)
}

\author{
Nikbakhtzadeh MR (1), Akbarzadeh K (2), Tirgari S (3)
}

(1) Department of Medical Parasitology and Entomology, College of Medical Sciences, Tarbiat Modares University, Tehran, Iran; (2) Iranshahr Station of Public Health Research, Iranshahr, Iran; (3) Department of Medical Entomology and Vector Control, School of Public Health, Tehran University of Medical Sciences, Tehran, Iran.

ABSTRACT: The genus Pachycondyla is a large group of ants in the Ponerini tribe, known mostly from tropical and subtropical regions. Pachycondyla sennaarensis, the so-called Samsum ant in the Middle East, is distributed throughout the African tropics, Arabian Peninsula and Iran, where it is responsible for many cases of insectinduced dermal lesions and systemic reactions in humans. Populations of $P$. sennaarensis were studied in two regions of Iran and some aspects of their biology, ecology and medical importance are herein presented. Colonies of $P$. sennaarensis contain less than 850 workers that live in complicated underground galleries approximately one meter deep. Because of the harsh weather conditions of southern Iran, they can survive only in human disturbed habitats with higher humidity. Neither a real queen (without reproductive division of labor) nor a caste system is found in a $P$. sennaarensis colony. Observations indicated that $P$. sennaarensis is omnivorous, feeding on seeds of various plants, dead ants of other species, the larvae of dipterans and a few other invertebrates. The effect of the $P$. sennaarensis sting is usually mild, resulting in papule formation, erythema and dermal itching. The abdominal gland secretion of $P$. sennaarensis is a complex mixture of saturated and unsaturated hydrocarbons and small amounts of terpenoids, ketones, pyrazines and phenolic compounds that are accompanied by straight-chain hydrocarbons. So far, no case of anaphylaxis has been reported in Iran, a fact probably due to the lack of proteins in $P$. sennaarensis venom. It appears that $P$. sennaarensis populations vary considerably in their toxin composition according to their geographic range, which may ultimately explain symptoms of different severity among local residents.

KEY WORDS: Samsum ant, sting, ants, Formicidae, Ponerinae, Pachycondyla.

CONFLICTS OF INTEREST: There is no conflict.

FINANCIAL SOURCE: TMU, Tehran.

\section{CORRESPONDENCE TO:}

MAHMOOD REZA NIKBAKHTZADEH, Department of Medical Parasitology and Entomology, Tarbiat Modares University, Tehran, PO Box 14115-331, Iran. Fax: +98 21 82884555. Email: nikbakht m@excite.com. 


\section{INTRODUCTION}

Ants (superfamily Formicoidea) are probably the most successful of all insect groups, occurring everywhere in terrestrial habitats (1). Ant species are grouped into the single family of Formicidae, which is further divided into 21 subfamilies (2), 296 genera and more than 11000 described species (1). One of the major ant subfamilies is the Ponerinae which is often considered "primitive" because its members show many of the putative ancestral traits (3). These include low queenworker dimorphism, small colony sizes and predatory behavior, all of which may explain the simple social structuring and simple communicative needs of ponerine ants (4). Ponerine ants are primarily insectivorous and forage outside their nest in order to capture their prey (5).

The ponerine genus Pachycondyla Smith 1858, with 200 described species, is a large group of ants in the tribe Ponerini, mostly known from tropics and sub-tropics (6). The generic names Brachyponera and Ectomomyrmex are synonymous with Pachycondyla. The nesting and social biology of Pachycondyla is variable $(7,8)$. This genus lives in colonies of a few dozen to a few thousand workers. Several species of Pachycondyla are specialized termite predators or are nectar feeders; however, most species are leaf litter inhabitants that are generalist scavengers or predators who subdue their prey with their venom $(9,10)$.

Adverse reactions have been reported in humans after being bitten or stung by ten genera from six subfamilies of such ants (11). Excluding the imported fire ants (Solenopsis spp.), Pachycondyla is responsible for most cases of anaphylaxis throughout the globe (11). The two most notorious species are $P$. chinensis and $P$. sennaarensis. Allergic and anaphylactic reactions from $P$. chinensis have been reported from China (12), Japan (13), Vietnam (14), New Zealand (15), Korea (16), Taiwan and the United States $(13,17)$. Similar problems after the stings of $P$. sennaarensis were first reported from the United Arab Emirates (18). Pachycondyla sennaarensis (Mayr, 1862), distributed throughout the African tropics, was first described as Ponera sennaarensis by Mayr in 1862 (19). It is an aggressive species from the Arabian Peninsula (20, 21). Dejean and Lachaud (22) who studied the species in Zaire, described it as partially feeding on seeds. Iranian Samsum ants were unknown until recently when Pachycondyla sennaarensis (Hymenoptera: Formicidae) was reported from southern and southeastern Iran (23, 24). Paknia believes that the evolution of omnivory, including seed consumption, from carnivory 
within this group allowed omnivorous taxa to better disperse across the native African boundaries with abundant prey (25). Winged dispersal of female reproductive forms does not seem to play an important role in the spread of $P$. sennaarensis to nonnative regions, such as the Arabian Peninsula and Iran $(25,26)$. It is thus assumed that human activities such as overseas trade, construction and irrigation of planted vegetation are the major means of introduction.

The ecology and the distribution of this species in Iran are not well established. Globally, there are also some variations in the clinical features of these medically important ants. Although abdominal gland secretions have been studied in several species of the genus Pachycondyla, no comprehensive study has been yet carried out on $P$. sennaarensis $(4,27)$. In addition to ecological studies, we have therefore studied abdominal glands of $P$. sennaarensis and herein present these findings in a medical context.

\section{MATERIALS AND METHODS}

\section{Field Collection}

Foraging workers of four colonies of $P$. sennaarensis were collected in Fajr Park (27.12N, 60.41E) and around Abshekan village (27.19N, 60.46E) from February to May 2007, while the field observations of the marked colonies which were located in Abshekan village (Figure 1) continued until October. Collected specimens were killed by freezing and carried in cold boxes to the laboratory where they were stored at $30^{\circ} \mathrm{C}$ until 2008 , when the workers were dissected for sample preparation. A sample of individuals was retained intact for morphological identification. 


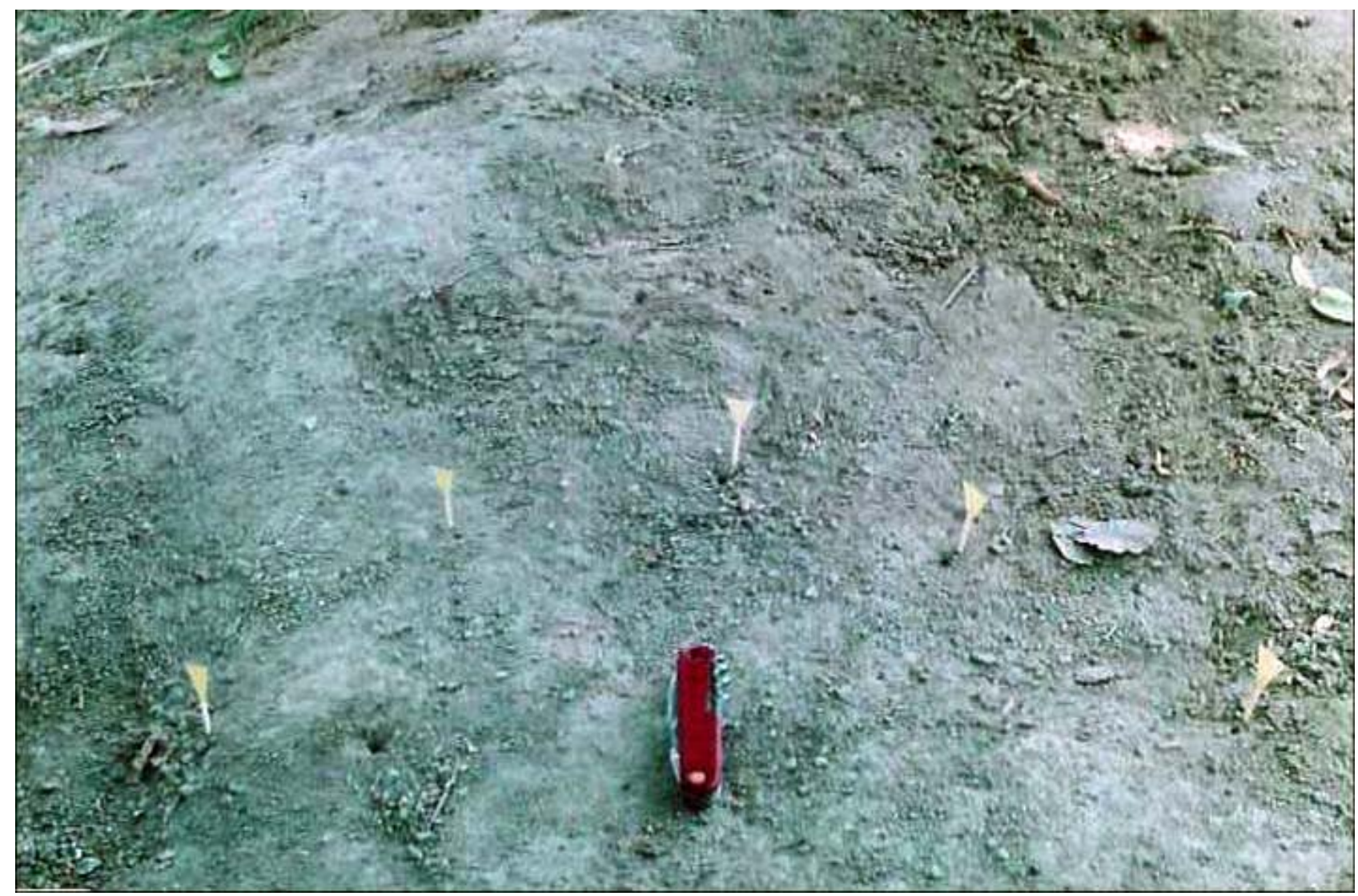

Figure 1. A marked colony of Pachycondyla sennaarensis in southeastern Iran. The small openings of the colony on the ground are indicated by triangular markers.

\section{Identification}

Identification to the species level was carried out by Prof. B. Bolton at Natural History Museum in London and Dr. J. L. Cook at the Sam Huston State University of Texas. All ants collected in the mentioned localities were confirmed as Pachycondyla sennaarensis (Hymenoptera: Formicidae, see Figure 2A). Voucher specimens are deposited in the laboratory of Medical Entomology at Tarbiat Modares University. 


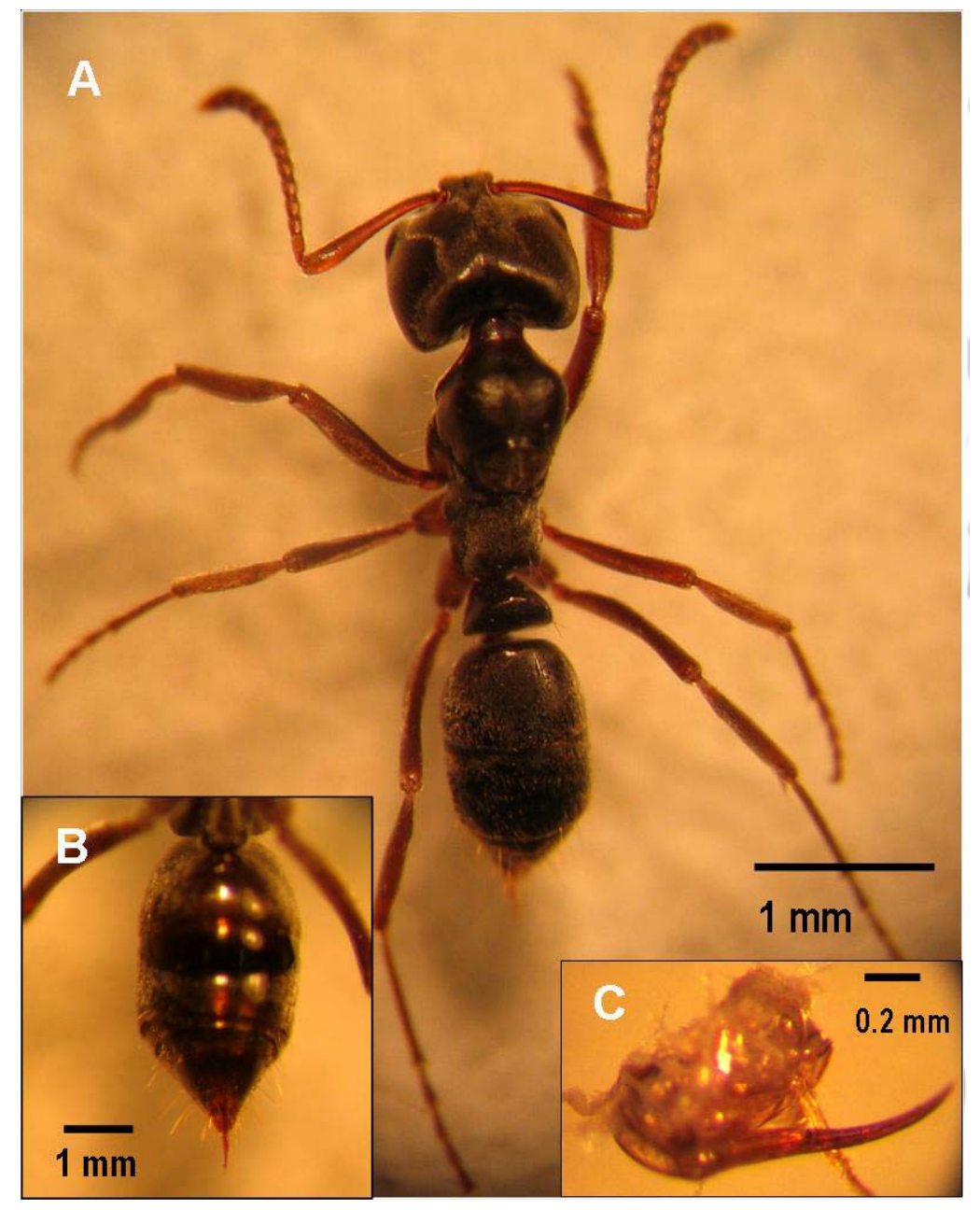

Figure 2. The Iranian Samsum ant $P$. sennaarensis: $(\mathbf{A})$ worker, $(\mathbf{B})$ the posterior abdominal sting and (C) the sting apparatus attached to the abdominal gland structure.

\section{Monitoring of Ant Behavior}

The ability of fertilized workers to found colonies was monitored under field conditions using 20 open Plexiglas cylinders (60 cm height $\times 30 \mathrm{~cm}$ diameter), which had been fixed at the soil depth of $20 \mathrm{~cm}$, at an alfalfa farm in Abshekan village. The farm was irrigated twice a week by flooding. One fertilized ant worker was introduced into each cylinder which was covered at top with a piece of polyester net to prevent escape. Cylinders were observed daily for 40 days.

\section{Clinical Features}

Symptoms, induced by the Samsum ant, Pachycondyla sennaarensis, were observed on hands of the authors $(n=3)$ at the TMU Lab. The forearm was exposed to the ants to be repeatedly stung after which the clinical trend of the symptoms was 
recorded for 72 hours. Basic emergency medical care was available and volunteers were monitored under direct supervision of medical staff.

\section{Preparation of Extract from Abdominal Glands and Chemical Analysis}

Workers $(n=7)$ were thawed in a refrigerator and then their abdominal gland structure, attached to the sting apparatus (Figures 2B and 2C), was pinched out in distilled water with the aid of a dissecting microscope (Stemi SRß, Zeiss, Germany). Dissected venom glands were placed in $0.5 \mathrm{~mL}$ microtubes and disrupted by ultrasonic waves (UP $400 \mathrm{~S} \Omega$, Hielscher, Germany) for three minutes in a cycle mode of 0.5 second, $50 \mathrm{kHz}$ in either $250 \mu \mathrm{L}$ hexane (chromatography grade, Merck, Germany) or $50 \mu \mathrm{L}$ of a 9:1 solution of acetonitrile and trifluoroacetic acid. The resulting mixtures were shaken for one minute and membranes were removed by centrifugation for five minutes at $3000 \mathrm{r} / \mathrm{m}$. The hexane-based extract was concentrated by nitrogen flow and examined by GC-MS on a Varian Star $3800 \AA$ instrument linked to a Varian Saturn $2000 \circledR$ Mass Selective Detector, set to monitor $\mathrm{m} / \mathrm{z} 40-350$ at $70 \mathrm{eV}$ with a scanning speed of $1 \mathrm{scan} / \mathrm{sec}$. The samples were analyzed using a fused silica capillary column $(50 \mathrm{~m} \times 0.25 \mathrm{~mm}$ ID, $0.12 \mu \mathrm{m}$ FT) coated with CP-Sil8cb (5\% phenyl, 95\% polydimethylsiloxane). The oven temperature was programmed to rise from $50^{\circ} \mathrm{C}$ to $300^{\circ} \mathrm{C}$ at $15^{\circ} \mathrm{C} /$ minute. The carrier gas was helium at $1.2 \mathrm{~mL} / \mathrm{min}$. The injector port temperature was held at $200^{\circ} \mathrm{C}$. The peak area of each component in the chromatogram was determined and then the percentage of each substance in the gland calculated by the Saturn ${ }^{\circledR}$ GC/MS Workstation computer package Saturn view ${ }^{\circledR}$ version 5.2.1, 1989-1998 (Varian Associates, Inc., USA).

High-performance liquid chromatography (HPLC) was performed using a Waters $6000 A \circledast$ pump and Waters $\mathrm{R} 401 \AA$ (USA) differential refractometer detector. Ten microliters of the acetonitrile/trifluoroacetic acid extract was injected into a $C_{18}$ reserved phase column (5 $\mu \mathrm{m}$, particle size; $220 \times 2.1-\mathrm{mm}$ column; Vydac) and separation was monitored at a flow rate of $20 \mu \mathrm{L} /$ minute (28).

\section{Chemical Identification}

Identification was primarily accomplished by using spectra from the NIST library (NIST Mass Spectrometry, 2007). Precise identification was based on comparison of GC retention time and mass spectra with either authentic or the laboratory- 
synthesized compound. Authentic trimethyl pyrazine, 2,5-piperazinedione, phenol2,4-bis (1,1 dimethylethyl), alkenes and methylated hydrocarbons were obtained from Sigma-Aldrich Chemie $\mathrm{GmbH}$ (Germany). Acetonitrile and trifluoroacetic acid were purchased from Merck (Germany). A commercial product consisting of pentadecan-2-one (Lancaster Synthesis Ltd., UK) was used as standard. A sample of 2,6,10-trimethylundecan-2,9-dien-4-one was synthesized through the Grignard reaction (29). Authentic samples of aliphatic alkanes were obtained from Accu Standard (USA).

\section{RESULTS}

\section{Bioecology of $P$. sennaarensis}

Pachycondyla sennaarensis build complicated underground galleries of about $1 \mathrm{~m}$ depth with small openings $(0.5 \mathrm{~cm}$ diameter) which include little circumferential compact soil. They establish their colony in humid microclimates, e.g. parks and greens, near irrigation channels, below concrete surfaces and in human and animal premises. Openings of a colony are circular (3-5 $\mathrm{mm}$ in diameter) and visible at the infested room corners. No colony was detected in dry sandy soils. None of the newly mated workers, which were placed in a Plexiglas cylinder, could establish a new colony. Fertilized wingless workers were observed on the periphery of colonies. These workers are $1 \mathrm{~mm}$ longer than the others and can be easily identified by observing the base of the loose wings on their thorax. The number of workers in a colony never exceeded 850. Our surveillance indicated that winged ants appear in early spring and autumn. Foraging is randomly carried out by workers with no tracing model to the food resource. Field observations showed that $P$. sennaarensis were omnivorous, feed on seeds of various plants, corpses of other ants, larvae of dipterans, a few species of Isoptera and some isopods such as Porcellio spp.

\section{Ant Sting and Clinical Manifestations}

A short while after being stung by a Samsum ant, small papules appeared (Figure $3 \mathrm{~A}$ ) whose diameters grew to about $0.5 \mathrm{~cm}$ in 3 to 5 minutes. In cases of multiplestings, papules became conjoined to form a nodule. Fine nodules were usually replaced by erythema (Figure 3B) and distinct inflammation in less than 15 minutes, but no pustule was observed. No visible symptom remained after 5 hours; however local itching that had commenced in the first minutes lasted for 24 hours. 
Nikbakhtzadeh MR et al. Bioecology and chemical diversity of abdominal glands in the iranian samsum ant Pachycondyla sennaarensis (Formicidae: Ponerinae). J Venom Anim Toxins incl Trop Dis. 2009;15(3):516

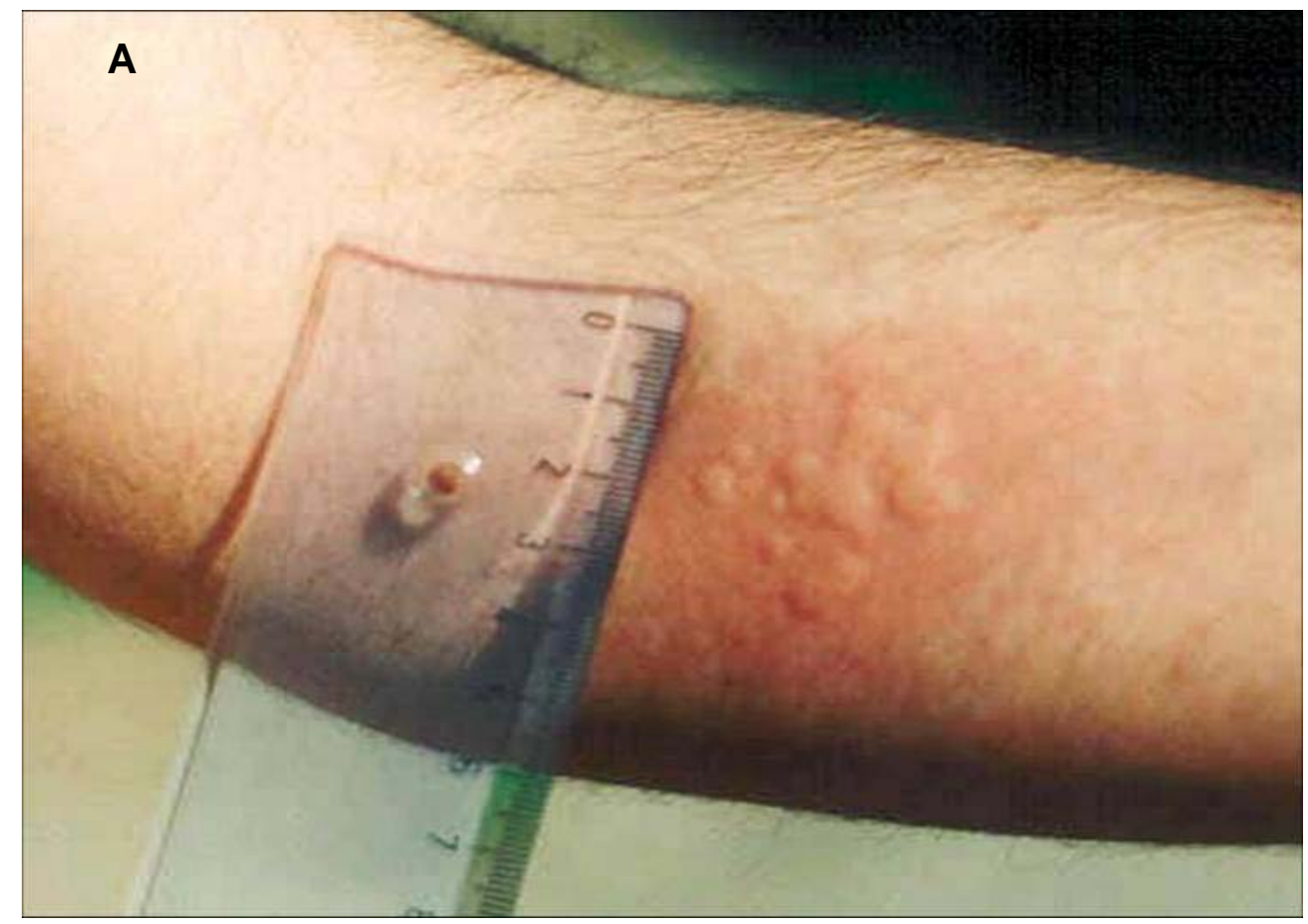

B

Figure 3. Clinical symptoms after $P$. sennaarensis sting: (A) papules are the first symptoms and are followed by (B) erythema in less than 15 minutes. 


\section{Remarkable Components of Abdominal Glands}

Abdominal gland secretions of $P$. sennaarensis are mainly a complex mixture of linear and methyl-branched hydrocarbons. The alkane series starts as undecane and continues to heptacosane. Heptadecane, nonadecane, pentadecane and lower concentrations of hexadecene, hexadecane and undecane constitute the highest volume of the glandular components (Table 1).

Abdominal secretions also include small amounts of terpenoids, mostly identified as 2,6,10-trimethylundecan-2,9-dien-4-one $\left(\mathrm{C}_{14} \mathrm{H}_{22} \mathrm{O}\right)$, 2,5-piperazinedione and trimethyl pyrazine $\left(\mathrm{C}_{7} \mathrm{H}_{10} \mathrm{~N}_{2}\right)$, which are all accompanied by straight-chain hydrocarbons. El mass spectra of pyrazine (Figure 4A) revealed major fragments at $m / z \quad 42$ and 81 with the molecular ion $\left(\mathrm{M}^{+}\right)$at $m / z$ 122. Mass spectra of $\mathrm{C}_{14} \mathrm{H}_{22} \mathrm{O}$ (Figure $4 \mathrm{~B}$ ) indicated characteristic fragments at $m / z 84$ and 124 with $\mathrm{M}^{+}$at $m / z 206$. Base peaks of 2,5-piperazinedione appeared correspondingly at $m / z 30,114,71$ and 28 (Figure 4C).

Interestingly, a minute amount of another structure of $\mathrm{C}_{14} \mathrm{H}_{22} \mathrm{O}$ was also eluted in some of our collected specimens with mass spectral (El mode) fragments at $m / z 191$ and 57 with the molecular ion $\left(\mathrm{M}^{+}\right)$at $\mathrm{m} / \mathrm{z} 206$ (Figure 4D), which are characteristics of phenol-2,4-bis (1,1 dimethylethyl). Confirmation was made via a comparison to the retention time and mass spectra of the injected authentic compound. The gland secretions also contained the methyl ketone, pentadecan-2-one, $\left(\mathrm{C}_{15} \mathrm{H}_{30} \mathrm{O}\right)$ with the mass spectra characteristic fragments at $m / z 58,59,43$ and $\mathrm{M}^{+}$at $m / z 226$ (Figure $4 \mathrm{E})$. The spectrum and retention times of the authentic material that we obtained were compared and proven to be the same as that of the ant. There was also a compound with base peaks at $\mathrm{m} / \mathrm{z} 55,82,96$ and 69 and a molecular mass of 278 (Figure 4F). Identification of this compound could not be confirmed, but mass spectra were consistent with a formula $\mathrm{C}_{20} \mathrm{H}_{38}$. Although they appeared in trace volumes, 2tridecyl acetate, dodecyl butyrate and 2- methyl hexadecanal (Table 1) were among the other interesting compounds that could be detected in the abdominal gland secretions of $P$. sennaarensis. Surprisingly, no peptide elution was monitored through a series of HPLC experiments. 
Nikbakhtzadeh MR et al. Bioecology and chemical diversity of abdominal glands in the iranian samsum ant Pachycondyla sennaarensis (Formicidae: Ponerinae). J Venom Anim Toxins incl Trop Dis. 2009;15(3):518

Table 1. Volume of the abdominal gland reservoir in Pachycondyla sennaarensis workers and composition of its chemical components based on GC-MS analyses ( $\mathrm{n}=$ 7)

\begin{tabular}{|c|c|c|}
\hline $\begin{array}{l}\text { Component } \\
\text { number }^{1}\end{array}$ & Compound & $\begin{array}{c}\text { Proportion } \\
(\%, \text { mean } \pm \text { SD })\end{array}$ \\
\hline 1 & 2,5-piperazinedione & $0.9 \pm 0.3$ \\
\hline 2 & Trimethyl pyrazine & $1.1 \pm 0.2$ \\
\hline 3 & Undecane & $4.6 \pm 0.85$ \\
\hline 4 & ${\text { Phenol-2,4-bis (1,1 dimethylethyl) }{ }^{2}}^{2}$ & $0.1 \pm 0.1$ \\
\hline 5 & 2,6,10-trimethylundecan-2,9-dien-4-one & $0.3 \pm 0.07$ \\
\hline 6 & Pentadecane & $14 \pm 2.3$ \\
\hline 7 & 4,11-dimethyltetradecane & $1 \pm 0.6$ \\
\hline 8 & 12-methylpentadecane & $3.2 \pm 1.9$ \\
\hline 9 & Hexadecene ${ }^{3}$ & $8.3 \pm 4.7$ \\
\hline 10 & Hexadecane & $9.1 \pm 2.8$ \\
\hline 11 & 2-tridecyl acetate & trace \\
\hline 12 & Heptadecane & $26 \pm 6.4$ \\
\hline 13 & Pentadecan-2-one & $1.2 \pm 0.01$ \\
\hline 14 & Octadecene & $3.6 \pm 1.3$ \\
\hline 15 & Octadecane & $3.4 \pm 0.7$ \\
\hline 16 & Dodecyl butyrate & trace \\
\hline 17 & 2-methylhexadecanal & $0.1 \pm 0.1$ \\
\hline 18 & Nonadecane & $19.6 \pm 7.2$ \\
\hline $19^{4}$ & $\begin{array}{c}\text { RT: } 20.1 \mathrm{~min}, \mathrm{M}^{+} 278, \mathrm{~m} / \mathrm{z} 55\left(100^{5}\right), 82(74), 96(60), 69 \\
(57), 41(55), 83(54), 81(52)^{6}\end{array}$ & trace \\
\hline 20 & Heneicosene & trace \\
\hline 21 & Heneicosane & $2.7 \pm 2.33$ \\
\hline 22 & $2,6,10,14$ tetramethyl hexadecane & $0.2 \pm 0.1$ \\
\hline 23 & Heptacosane & $\overline{0.6 \pm 0.3}$ \\
\hline & Volume of abdominal gland reservoir $(\mu \mathrm{L})$ & $2.7 \pm 0.6$ \\
\hline
\end{tabular}

*Average values higher than $5 \%$ are written in bold; when the value is underlined not all the individuals within the four studied colonies contained the compound in detectable amounts.

${ }^{1}$ Components are arranged according to their elution time.

${ }^{2}$ Could be only detected in the specimens collected in Abshekan village (27.19N, 60.46E).

${ }^{3}$ Present as two isomers in some specimens.

${ }^{4}$ This secretion consisted of a probable terpene that could not be identified, so its approximate retention time and the principal mass spectral ions are given.

${ }^{5}$ Recorded intensity.

${ }^{6}$ Other $\mathrm{m} / \mathrm{z}$ represented a weak ion. 

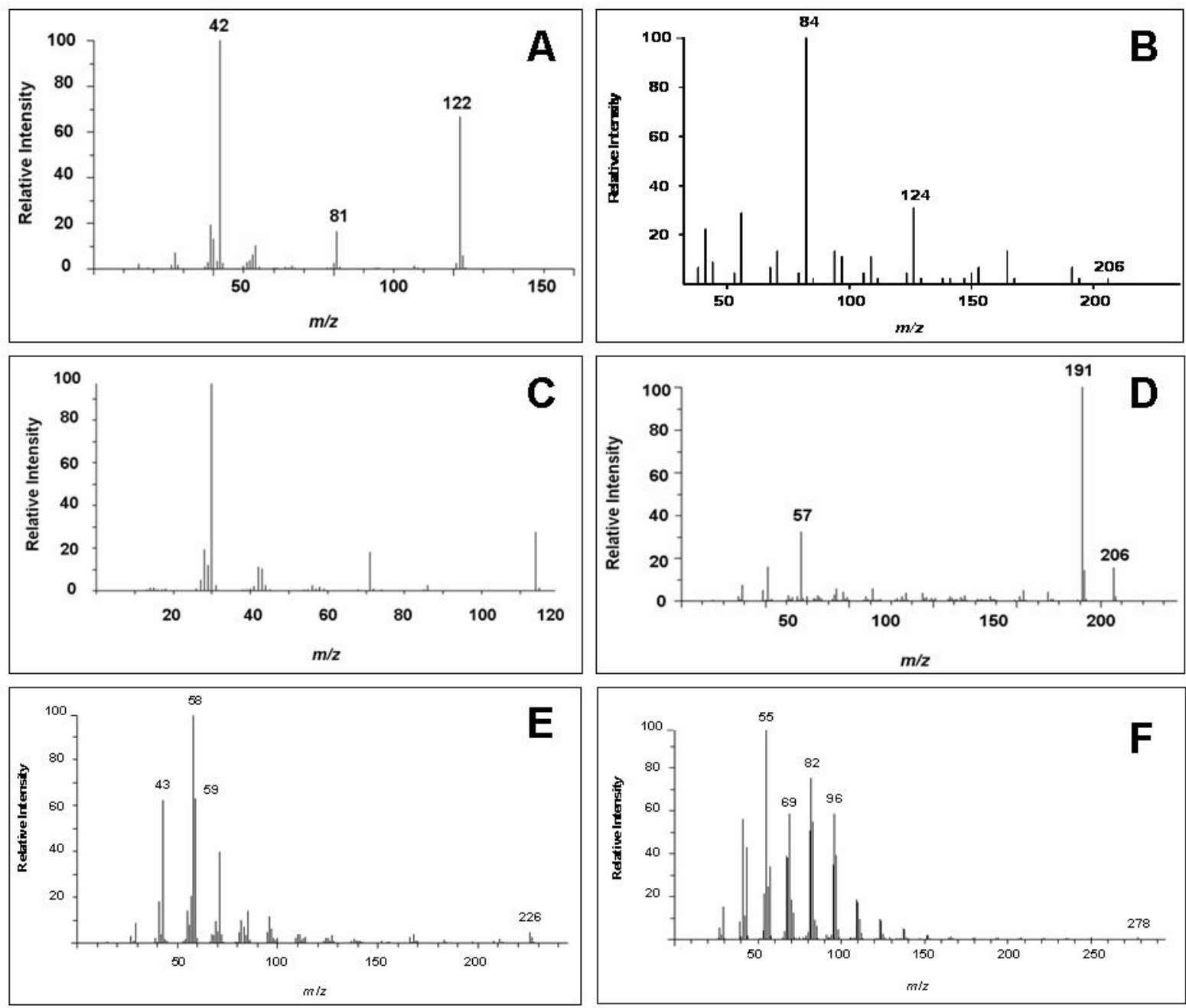

Figure 4. Mass spectra $(70 \mathrm{eV})$ of $(\mathbf{A})$ trimethyl pyrazine with base peaks at $\mathrm{m} / \mathrm{z} 42$ and 81; (B) 2,6,10-trimethylundecan-2,9-dien-4-one with fragments at $m / z 84$ and 124; (C) 2,5-piperazinedione with characteristic fragments at $m / z 30,114,71$ and 28 ; (D) phenol-2,4-bis (1,1 dimethylethyl) with mass spectral fragments at $\mathrm{m} / \mathrm{z} 191$ and 57; (E) pentadecan-2-one with the spectral fragments at $\mathrm{m} / \mathrm{z} 58,59$ and 43 , and (F) the unknown compound with the probable chemical formula $\mathrm{C}_{20} \mathrm{H}_{38}$. Electron ionization provides base peaks at $m / z 55,82,96$ and 69 and the $\mathrm{M}^{+}$at $m / z 278$.

\section{DISCUSSION}

Pachycondyla sennaarensis is a savannah and forest species in Africa (30), which requires high humidity, but in Iran it is more associated with humans in urban and rural localities. Because of the harsh weather conditions of southern Iran, it can survive only in well-irrigated agricultural ecosystems and human dwellings that provide protection from excessive water loss. Pachycondyla species are usually 
considered specialist predators (31). McGlynn reported 147 species of ants that have been collected in non-native habitats in various parts of the world (32).

Although Iranian Samsum ants share some characteristics of invasive species (25), it is widely believed that they should be still considered a tramp species. Unlike invasive species, tramp species do not spread rapidly or dominate new environments but are tied to human activities. Such species prefer disturbed habitats in close association with humans. The incidence of stings by these ants is likely to increase with the accelerating rate of urbanization. Urban development and sprawl disrupt natural ecosystems, bringing humans in contact with those species that thrive in disturbed habitats. In addition, increased trade and travel provide invasion routes for exotic ants (11).

Anaphylaxis has been attributed to both of the medically important species, $P$. sennaarensis and $P$. chinensis $(13,18)$. Despite reports on the severe clinical symptoms, e.g. systemic allergic reactions, anaphylactic shocks, asthma and even death, in response to stings and bites from other ant species (11), the effects of the Iranian populations of $P$. sennaarensis are usually mild, i.e. at the worst case, forming papules and dermal itching due to multiple stinging. It should be noted that clinical manifestations due to ant stings are affected by the quantity of venom injected, the location of the stung area in terms of skin thickness, proximity to a vessel, its relation to extremities, head and neck or mucosa and finally the immune status of the patient. The efficacy of the sting as the defense weapon of ants is based on the toxic properties of the secretion produced by their venom gland. It is believed that the ability to produce pain is, in defensive terms, the most important aspect of these venoms (33). Fire ant venom contains piperidines and pyrazines, which cause a burning sensation in stung individuals, and a small percentage $(<1 \%$ volume of the venom secretion) of proteins, which can cause anaphylaxis in those stung (34). Peptides are also responsible for inducing pain and tissue damage (27). We believe that lack of the systemic reactions after stings of the Iranian populations of $P$. sennaarensis is due to the absence of protein components in their venom secretions. The non-peptide venom constituents of $P$. sennaarensis were not known until this study. These components are not only species-specific, but different among geographical populations of a single species. Piperidines have been twice detected in Pachycondyla spp. In the first case 2,5-piperazinedione was separated from a multi-protein matrix in the venom of Pachycondyla apicalis and in the second, 2,6- 
dimethyl piperidine was isolated from Pachyconcondyla tarsata (4, 35). Pyrazines, which are frequently found in formicid ants, are formed from amino acids. This group of chemicals has been repeatedly reported from the venom of ponerine and myrmecine species. For example, small amounts of 2,5-dimethylpyrazine and 2,5dimethyl-3-ethylpyrazine were found in the venom gland of Pachycondyla obscuricornis (4).

Venom gland components of only 19 out of 200 described species of the genus Pachycondyla have been so far examined. Peptides and proteins were found in 15 species; however, in some cases no explicit reference was made to the involved compounds (27). Proteins were identified from the venom secretions of $P$. villosa (36), P. insularis and P. tridentata (37), P. apicalis (35) and P. tarsata (4). Orivel and Dejean (27) reported that Pachycondyla venom contained mostly histolytic and neurotoxic peptides. The occurrence of peptides was reported in the venom secretions of $P$. sennaarensis and $P$. obscuricornis (27), but it could not be verified by subsequent studies of other workers (our unpublished data from HPLC and in reference 4). Such differences may reflect natural variation among geographic populations of $P$. sennaarensis. This might also provide an explanation for the different severity of symptoms among stung persons on the two sides of the Persian Gulf. The venom gland components of $P$. chinensis are only partially described and appear to contain amines, formic acid, histamines, hyaluronidase, phospholipases and terpenes (13).

Another remarkable chemical detected in our study was 2,6,10-trimethylundecan-2,9dien-4-one, which along with its other structurally similar sesquiterpenoids was once reported to originate from female cuckoo bees, Nomada lathburiana (29). It allegedly plays a repellent or defensive role, although no supporting test was carried out. The phenolic compound Phenol-2,4-bis (1,1 dimethylethyl) has been reported in the mycelia of Tuber borchii (Tuberales) while no record exists on its occurrence in insects (38). Extremely low amounts of this compound could be detected in the colonies of Abshekan village, but was totally absent among the Fajr Park specimens which had indicated a considerable titer of 2,6,10-trimethylundecan-2,9-dien-4-one.

Pentadecan-2-one has been repeatedly found in the abdominal glands of ants. Of 15 examined species of the genus Myrmecocystus, ten were found to bear pentadecan2-one in the Dufour glands of workers (39). Similarly, variable volumes of pentadecan-2-one were reported in different species within Cataglyphis bicolor group 
(40). 2-Alkanones are also among the typical products of a number of Lasius $(41,42)$ and Acanthomyops species (43). We also detected small amounts of an unknown compound with the probable chemical formula $\mathrm{C}_{20} \mathrm{H}_{38}$, although we were unable to precisely determine its structure. Such a formula was found in $P$. obscuricornis and $P$. apicalis and characterized as a ditepene (4). The occurrence of diterpenes in combination with hydrocarbons appears to be common in members of the tribe Ponerini.

A very low titer of 2-tridecyl acetate was once found in the formicine ant, Cataglyphis viaticus, while dodecyl butyrate was isolated from Cataglyphis bombycinus (40). No explanation has ever been provided on the probable function of these compounds in the studied ant species.

It is still not known why only the two species of $P$. chinensis and $P$. sennaarensis are of public health importance, while the substances required to induce symptoms are found in the venom glands of a much broader spectrum of species $(4,27)$. Two reasons for the paucity of sting reaction reports attributed to the other species can be hypothesized. First, most stings were not sufficiently severe for victims to seek medical attention. Second, the causative agent in cases of severe reactions may have been misidentified by victims and medical practitioners as another ant or arthropod species. Morgan et al. examined Pachycondyla apicalis and found a mixture of five proteins. They believe that compounds such as pyrazines and piperazinedione in the venom secretions of $P$. apicalis are made from amino acids (4). Pyrazines of the abdominal secretions of $P$. sennaarensis and $P$. obscuricornis could not be formed from amino acids because no peptide or protein was detected in their venom gland. Plant sources may explain the origin of such compounds (4).

After many years of studying stinging ants, many questions on the biology, ecology, behavior, defense and medical importance of these species have remained. Our working group is currently working on different geographic populations of $P$. sennaarensis in the hope of finding answers to some of these emerging questions.

\section{ACKNOWLEDGEMENTS}

The authors express their immense gratitude to Prof. B. Bolton (London) and Dr. J. L. Cook (Texas) who identified our specimens from southeastern and southern Iran. We also thank Dr. John Sloggett (the Netherlands) and Dr. Mohammad Omrani (Shahrekord University of Medical Sciences) for reviewing a draft of the manuscript 
and improving the English text. This project has been financially supported by a grant from TMU, Tehran, to M.R. Nikbakhtzadeh under reg. number 51/60890.

\section{REFERENCES}

1. Bolton B. Identification of the ant genera of the world. Cambridge, Massachusetts: Harvard University Press; 1994. 232 p.

2. Bolton B. Synopsis and classification of Formicidae. Mem Am Entomol Inst. 2003;71:1-370.

3. Peeters C. Morphologically 'primitive' ants: comparative review of social characters, and the importance of queen-worker dimorphism. In: Choe JC, Crespi BJ, editors. Social Behaviour in Insects and Arachnids. Cambridge: Cambridge University Press; 1997. 372-91 p.

4. Morgan ED, Jungnickel H, Keegans SJ, do Nascimento RR, Billen J, Gobin B, Ito F. Comparative survey of abdominal gland secretions of the ant subfamily Ponerinae. J Chem Ecol. 2003;29(1):95-114.

5. Ortiz G, Camargo Mathias MI. Venom gland of Pachycondyla striata worker ants (Hymenoptera: Ponerinae). Ultrastructural characterization. Micron. 2006;37(3):2438.

6. Bolton B. A taxonomic and zoogeographical census of the extant ant taxa (Hymenoptera: Formicidae). J Nat Hist. 1995;29(4):1037-56.

7. Fukuzawa M, Arakura F, Yamazaki Y, Uhara H, Saida T. Urticaria and anaphylaxis due to sting by an ant (Brachyponera chinensis). Acta Derm Venereol. 2002;82(1):59.

8. Kim S, Hung C. A case of anaphylaxis by ant (Ectomomyrmex spp.) venom and measurements of specific IgE and IgG subclasses. Yonsei Med J. 1992;33(3):281-7.

9. Mill AE. Predation by the ponerine ant Pachycondyla commutata on termites of the genus Syntermes in Amazonian rain forest, Brazil. J Nat Hist. 1984;18(3):405-10. 10. Wild AL. The genus Pachycondyla (Hymenoptera: Formicidae) in Paraguay. Bol Mus Nac Hist Nat Parag. 2002;14(1-2):1-8.

11. Klotz JH, deShazo RD, Pinnas JL, Frishman AM, Schmidt JO, Suiter DR, Price GW, Klotz SA. Adverse reactions to ants other than imported fire ants. Ann Allergy Asthma Immunol. 2005;95(5):418-25. 
12. Zhenghui X. A taxonomic study of the ant genus Brachyponera Emery in southwestern China (Hymenoptera: Formicidae: Ponerinae). J Southwest For Coll. 1994;14(3):181-5.

13. Nelder MP, Paysen ES, Zungoli PA, Benson EP. Emergence of the introduced ant Pachycondyla chinensis (Formicidae: Ponerinae) as a Public Health Threat in the Southeastern United States. J Med Entomol. 2006; 43(5):1094-8.

14. Eguchi K, Viet BT, Yamane SK, Okido H, Ogata K. Ant faunas of Ba Vi and Tam Dao, North Vietnam (Insecta: Hymenoptera: Formicidae). Bull Inst Trop Agric Kyushu Univ. 2005;27:77-98.

15. Green OR. New Zealand ants (Hymenoptera: Formicidae). Distribution and effects. In: Proceedings of the $41^{\text {st }}$ Annual Conference of the Entomological Society of New Zealand; 1992; Hutt Valley, New Zealand. Heretavnga: Entomological Society of New Zealand; 2002. 67-72 p.

16. Cho YS, Lee YM, Lee CK, Yoo B, Park HS, Moon HB. Prevalence of Pachycondyla chinensis venom allergy in an ant-infested area in Korea. J Allergy Clin Immunol. 2002;110(1):54-7.

17. Smith DR. Formicoidea. In: Krombein KV, Hurd PD, Smith DR, Burks BD, editors. Catalog of hymenoptera in north america north of Mexico, vol. 2. Apocrita (Aculeata). Washington, DC: Smithsonian Institution Press; 1979. 1323-467 p.

18. Dib G. Allergie à la fourmi Pachycondyla sennaarensis aux Émirats Arabes Unis. Bull Soc Path Ex. 1992;85(5):400.

19. Taylor B. The ants of sub-Saharan Africa (Hymenoptera: Formicidae) with catalogue notes on all ant species described from sub-Saharan Africa [internet]. $9^{\text {th }}$ ed. 2007. Available from: http://antbase.org/ants/africa/.

20. Collingwood CA. Hymenoptera: Fam. Formicidae of Saudi Arabia. In: Wittmer W, Büttiker W, editors. Fauna of Saudi Arabia. Basle: Arnold Fricker AG; 1985. 230-302 p. 7 vol.

21. Collingwood CA, Agosti D. Formicidae (Insects: Hymenoptera) of Saudi Arabia (Part 2). In: Büttiker W, Krupp F, editors. Fauna of Saudi Arabia. Basle: Pro Entomologia (Natural History Museum); 1996. 300-385 p. 15 vol.

22. Dejean A, Lachaud JP. Ecology and behaviour of the seed-eating ponerine ant Brachyponera senunrensis (Mayr). Insectes Soc. 1994;41(2):191-210. 
23. Paknia O. Study of fauna and geographical distribution of stinging ants (Hymenoptera: Formicidae) and their medical importance in lar city (lar county) [Master's thesis]. Tehran: College of Medical Sciences of Tarbiat Modares University; 2002. $187 \mathrm{p}$.

24. Akbarzadeh K, Tirgari S, Nateghpour M, Abai MR. The first occurrence of fire ant Pachycondyla sennaarensis (Hym.: Formicidae), Southeastern Iran. Pak J Biol Sci. 2006;9(4):606-9.

25. Paknia O. Distribution of the introduced ponerine ant Pachycondyla sennaarensis (Hymenoptera: Formicidae) in Iran. Myrmecol News. 2006;8: 235-8.

26. Collingwood CA, Tigar BJ, Agosti D. Introduced ants in the United Arab Emirates. J Arid Environ. 1997;37(3):505-12.

27. Orivel J, Dejean A. Comparative effect of the venoms of ants of the genus Pachycondyla (Hymenoptera: Ponerinae). Toxicon. 2001;39(2-3):195-201.

28. Orivel J, Redeker V, Le Caer JP, Krier F, Revol-Junelles AM, Longeon A, Chaffotte A, Dejean A, Rossier J. Ponericines, new antibacterial and insecticidal peptides from venom of the ant Pachycondyla goeldii. J Biol Chem. 2001;276(21):17823-9.

29. Francke W, Krohn S, Tengö J. Identification of new sesquiterpenoids in cephalic secretion of cuckoo bee, Nomada lathburiana (Apoidea, Anthophoridae). J Chem Ecol. 1991;17(3):557-66.

30. Wheeler WM, Bequaert JC, Bailey IW, Santschi F, Mann WM, Lang H, Chapin JP. Ants of the American Museum Congo Emedition. A contribution to the myrmecology of Africa. 1. on the distribution of the ants of the Ethiopian and Malagasy regions. Bull Am Mus Nat Hist. 1922;45:13-37.

31. Andersen AN. Functional groups and patterns of organization in North American ant communities: a comparison with Australia. J Biogeography. 1997;24(4):433-60.

32. Mcglynn TP. The worldwide transfer of ants: geographical distribution and ecological invasions. J Biogeography. 1999;26(3):535-48.

33. Schmidt JO. Allergy to Hymenoptera venoms. In: Piek T, editor. Venoms of the hymenoptera. New York: Academic Press; 1986. 509-46 p.

34. Deshazo RD, Butcher BT, Banks WA. Reactions to the stings of the imported fire ant. N Engl J Med. 1990;323(7):462-6.

35. Cruz López LC, Morgan ED. Explanation of the bitter taste of the venom of the ponerine ant Pachycondyla apicalis. J Chem Ecol. 1997;23(3):705-12. 
36. Blum MS, Hermann HR. Venoms and venom apparatuses of Formicidae. In: Bettini S, editor. Arthropod venoms, vol. 48, Handbook of experimental pharmacology. Berlin: Springer; 1978. 801-96 p.

37. Maschwitz U, Jessen K, Maschwitz E. Foaming in Pachycondyla: a defence mechanism in ants. Behav Ecol Sociobiol. 1981;40(2):87-93.

38. Tirillini B, Verdelli G, Paolocci F, Ciccioli P, Frattoni M. The volatile organic compounds from the mycelium of Tuber borchii Vitt. Phytochem. 2000;55(8):983-5.

39. Lloyd HA, Blum MS, Snelling RR, Evans SL. Chemistry of mandibular and dufour's gland secretions of ants in genus Myrmecocystus. J Chem Ecol. 1989;15(11):2589-99.

40. Gökçen OA, Morgan ED, Dani FR, Agosti D, Wehner R. Dufour gland contents of ants of the Cataglyphis bicolor group. J Chem Ecol. 2002;28(1):71-87.

41. Regnier FE, Wilson EO. The alarm-defence system of the ant Lasius alienus. J Insect Physiol. 1969;15:893-8.

42. Bergström G, Löfquist J. Chemical basis for odour communication in four species of Lasius ants. J Insect Physiol. 1970;16:2353-75.

43. Regnier FE, Wilson EO. The alarm-defence system of the ant Acanthomyops claviger. J Insect Physiol. 1968;14:955-70. 